REVIEW ARTICLE OPEN

\title{
Review of low-cost point-of-use water treatment systems for developing communities
}

\author{
Ching Kwek Pooi iD ${ }^{1}$ and How Yong $\mathrm{Ng}^{1}$
}

For communities in developing countries, the majority of drinking water-related issues are due to pathogens from poor sanitation, resulting in infection and diarrhea. One cause of this is that these communities often do not have access to centralized water treatment facilities. Point-of-use (POU) systems are key solutions for treating water in developing communities; they are typically user-friendly, low cost, low maintenance, and grid-independent. Importantly, they treat and reduce the number of pathogens in water supplies, and many POU systems have been deployed and used by these communities, improving their livelihood. This review focuses on POU systems that cater to households or communities, with the aim to examine and evaluate technologies that have been implemented in POU systems in the past decade.

npj Clean Water (2018)1:11; doi:10.1038/s41545-018-0011-0

\section{INTRODUCTION}

Water is required for sustaining life. It is also used in many anthropogenic activities such as agriculture, washing, and industries. While almost all of the people living in the developed region have access to improved drinking water, more than $30 \%$ of people living in the least developed countries do not have access to improved drinking water. ${ }^{1}$ Improved water source, according to the WHO/UNICEF Joint Monitoring Program (JMP) method, refers to water from piped network, tube wells, protected dug wells, springs, and rainwater collection. In past decades, awareness and advancement in water treatment and distribution had allowed many to gain access to improved drinking water sources. From 1990 to 2005, more than 1.1 billion people worldwide had gained access to improved drinking source, with $83 \%$ of people worldwide having access to improved drinking water source. ${ }^{2}$ However, an estimate of 663 million people still lack access to improved drinking water, consuming untreated water from wells, springs, and surface water. ${ }^{1}$ The use of unimproved water source will cause users to be susceptible to waterborne diseases.

Poor sanitation and hygiene cause pathogens to contaminate surface water and groundwater. Ingestion of contaminated water often results in waterborne disease, causing one to experience health symptoms such as diarrhea, vomiting, and gastroenteritis., ${ }^{3,4}$ Diarrhea is the most common symptom in waterborne disease, impairing societies socially and economically. In 1996, diarrhea was estimated to cost at least R3.0 billion in South Africa, with a total social cost of at least $1 \%$ of the South Africa GDP. ${ }^{5}$ Every year, there were 1.7 billion cases of diarrhea. ${ }^{6}$ It also claims the lives of 525,000 children below the age of 5 each year. Diarrhea is a result of infection in the intestinal tract. One will experience three or more liquid/loose stools in a day, causing dehydration. Life will also be at risk if the electrolytes and water are not replaced. Prolonged diarrhea will also result in malnutrition, making one more susceptible to further diarrheal episodes. Majority of the diarrhea cases in developing countries are mainly caused by Escherichia coli, Enterococcus, Cryptosporidium, and rotavirus. $^{4,6-9}$ Therefore, the drinking water guidelines set by World Health Organisation (WHO) have indicated that fecal coliform must not be detected in drinking water and its corresponding distribution system. ${ }^{10}$

Waterborne diseases can be circumvented by proper water treatment. In developed countries and major city areas, water supplies are primarily managed by centralized water treatment systems. Conventional centralized water treatment systems consist of essential processes to remove harmful microorganisms. ${ }^{11}$ Treated water are then distributed to households via extensive piping systems. However, in developing countries and rural areas, the upfront cost of a centralized water treatment and distribution system, due to the low density of houses, hindered its installation. ${ }^{12}$ For these areas, adoption of on-site water treatment and storage system is a feasible mean. Point-of-use (POU) technologies are on-site water treatment systems that reduce pathogens in water sources prior to consumption. Numerous technologies had emerged and implemented in POU treatment systems in the past decade. This paper aims to examine and evaluate the technologies developed in the past decade that are used in POU treatment systems for developing communities to remove pathogens and reduce diarrhea episodes.

\section{TECHNOLOGIES FOR POU WATER TREATMENT}

Although there are many advanced water treatment technologies available, the technologies implemented in low-cost POU treatment systems are mainly characterized as mature and fundamental, aiming to remove waterborne pathogens. The available technologies are mainly flocculation and coagulation, filtration, and disinfection. Flocculation and coagulation remove the turbidity in the water, which reduces the supporting structure of microorganisms. This resulted in the removal of microorganisms. ${ }^{13}$ Filtration removes microorganisms by size exclusion, whereby microorganisms larger than the pore size of the filter will be retained within the system. ${ }^{11}$ Disinfection is the inactivation and ${ }^{1}$ Centre for Water Research, Department of Civil and Environmental Engineering, National University of Singapore, 1 Engineering Dr. 2, Singapore 117576, Singapore
Correspondence: How Yong. Ng (howyongng@nus.edu.sg)

Received: 19 August 2017 Revised: 3 April 2018 Accepted: 11 April 2018

Published online: 06 August 2018 

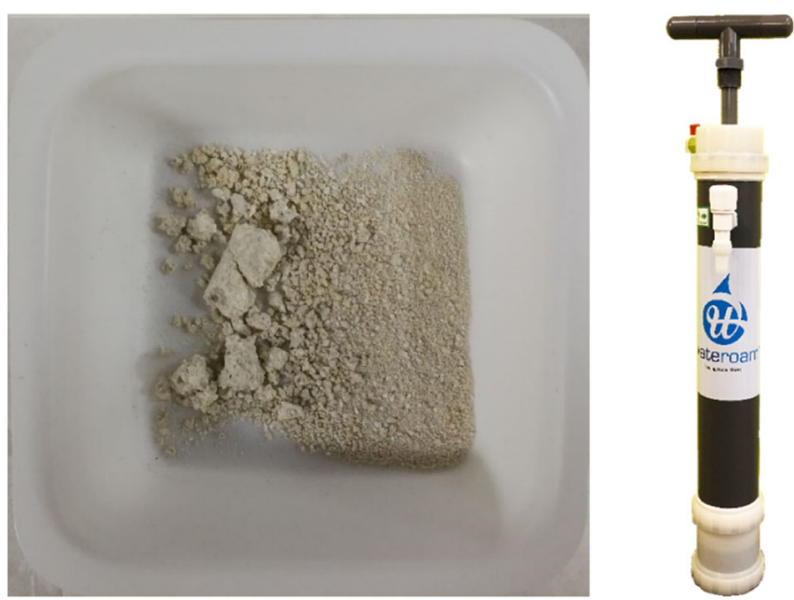

Fig. 1 Photographs of (left) bioflocculant and (right) WateROAM's portable membrane system (reproduced with permission from WateROAM)

destruction of microorganisms in the system to a safe level. ${ }^{14}$ Photographs of a flocculant and a membrane system are shown in Fig. 1.

\section{Coagulation and flocculation}

Coagulation and flocculation are low energy and reliable water treatment processes. Coagulation is the destabilization of smaller particles $(0.01-1 \mu \mathrm{m})$, resulting in the formation of larger particles. Flocculation is the formation of flocs from the destabilized particles. ${ }^{15}$ The flocculated particles can then be removed via settling or filtration.

Coagulation is able to effectively remove turbidity, colloids, ${ }^{16}$ and protozoan cysts. ${ }^{11}$ Coagulation, however, is unable to achieve a stable coliform removal. ${ }^{17}$ It has to be coupled with additional treatment process to improve the overall pathogen removal efficiency. When coagulation is used as a pretreatment or together with a membrane process, it can improve the removal of Cryptosporidium, ${ }^{18}$ E. coli and MS2. ${ }^{19}$ In addition, coagulation will improve the disinfection process by removing turbidity and reduce the scavenging of disinfectant by natural organic matters. ${ }^{20}$

The effective use of conventional coagulants such as alum, iron salt, and lime requires proper training and technical skills. Therefore, in the past, it had been mostly deployed for communal use in rural regions. Direct household usage of coagulant is rare. $^{16,21}$ However, in the past decade, optimization of coagulant dosage, development of natural coagulants, and addition of disinfectant have allowed manufacturers, such as Procter \& Gamble Co. (P\&G) and Poly Glu International Co. to produce coagulants/flocculants that are stored in small POU sachets. This makes it easier for usage and distribution.

The PUR sachet from P\&G is a combined flocculation/disinfection system. Ferric sulfate flocculates the destabilized particles within the water, while the calcium hypochlorite disinfects the water. ${ }^{22}$ In a study in western Kenya, sachets from P\&G of different dosages were used to treat turbid water of various sources. In the study, high dose formulation of the flocculant-disinfectant product achieved water quality with mean $E$. coli concentration of $0 \mathrm{mg} / \mathrm{L}$. The low dose formula, when used in high turbid water, was unable to consistently achieve drinking water quality. ${ }^{17}$ The use of $P \& G$ 's flocculant-disinfectant sachet in rural Guatemala reduced the episode of diarrhea per person by $23.8 \% .^{23}$ In a case study by P\&G in Vietnam, the PUR sachets achieved $>5$ log virus removal. 4 log removal and 3.6 log removal were also achieved for Cryptosporidium and Giardia, respectively. ${ }^{22}$ The PUR sachet was also shown to be able to achieve $>99 \%$ arsenic removal and $>8.2 \log$ removal of $E$. coli. ${ }^{21}$

Polyglutamic acid (PGA) is a natural, biodegradable, and edible bio-flocculant that is used at industrial scale ${ }^{24}$ and is the main ingredient in the Poly Glu sachet. It is produced from Bacillus licheniformis and Bacillus subtilis. ${ }^{25}$ PGA has high flocculating activity and high yield, resulting in the production of a smaller volume of sludge. It has better performance than aluminum sulfate in turbidity removal. ${ }^{26}$ Unlike the inorganic coagulant/ flocculant, suspended solids removal by PGA is dose-dependent and is independent of temperature and $\mathrm{pH}$, making it an ideal option for treating a wide range of water. ${ }^{27-30}$ PGA is also capable of adsorbing copper ions, removing harmful copper ions from the water source. ${ }^{31}$ In addition, in a patent submitted by Masamichi Mutou, a mixture containing $\mathrm{Y}$-PGA with cross-link product of $\mathrm{Y}^{-}$ PGA, sodium, calcium, and aluminum was able to inactivate microorganism. ${ }^{32}$ The components mentioned in the patent are used in PGa21, an ingredient used in PolyGlu; hence reducing the need for additional disinfectant within the PolyGlu sachet. However, the lack of residual chlorine may result in recontamination.

Coagulation and flocculation have shown success in treating drinking water and are mainly used for high turbid water. However, coagulation and flocculation cannot be a standalone water treatment solution. In the PUR sachet, disinfectants were added for effective removal of the pathogen. PolyGlu, on the other hand, requires proper water storage to prevent recontamination. While the PUR sachet and PolyGlu sachet had shown positive results in the removal of arsenic and copper, more studies are required to evaluate the effectiveness in removal of other potential heavy metals that can potentially reside in water sources. In addition, POU coagulant and flocculant are for single-use. This makes the process expensive in the long run. Ferric sulfate, a common coagulant, has shown potential in recovery and reuse. ${ }^{33}$ It can be explored to lower the operating expense (OPEX) of drinking water treatment in developing communities. Electrocoagulation, a process that generates aluminum hydroxide coagulant, has also shown potential in decentralized water treatment. Wind-powered electrocoagulation system was capable of removing up to $90 \%$ of microalgae and $97 \%$ of dissolved dye from synthetic wastewater within 72 h. $^{34}$ This process demonstrated its ability to remove both pathogen and dissolved chemicals.

\section{Filtration}

Filtration is a simple water treatment process capable of removing colloids, suspended solids, and pathogens from drinking water sources. Its main removal mechanism is size exclusion. A welldesigned filtration system will be able to generate a clean stream of drinking water. The size of different constituents commonly found in water sources and the pore size of conventional filtration process are summarized in Fig. 2. Filtration technologies implemented in POU are mainly biosand filtration (BSF) and membrane filtration.

In membrane filtration, external driving force is typically required to achieve the desired flow rate, and the external driving force required shall depend on the membrane pore size, surface area, and influent water quality. Compared to a membrane with larger surface area and pore size, higher applied pressure is required to filter water across a smaller membrane area with smaller pore size. In addition, maintenance is required in the filtration process. After prolong period of filtering, a foulant layer will be deposited on the filter layer. In sand filtration, flux can be recovered by backwash. In membrane system, backwash removes the reversible fouling, while chemical cleaning is required to remove biofouling and scaling. 


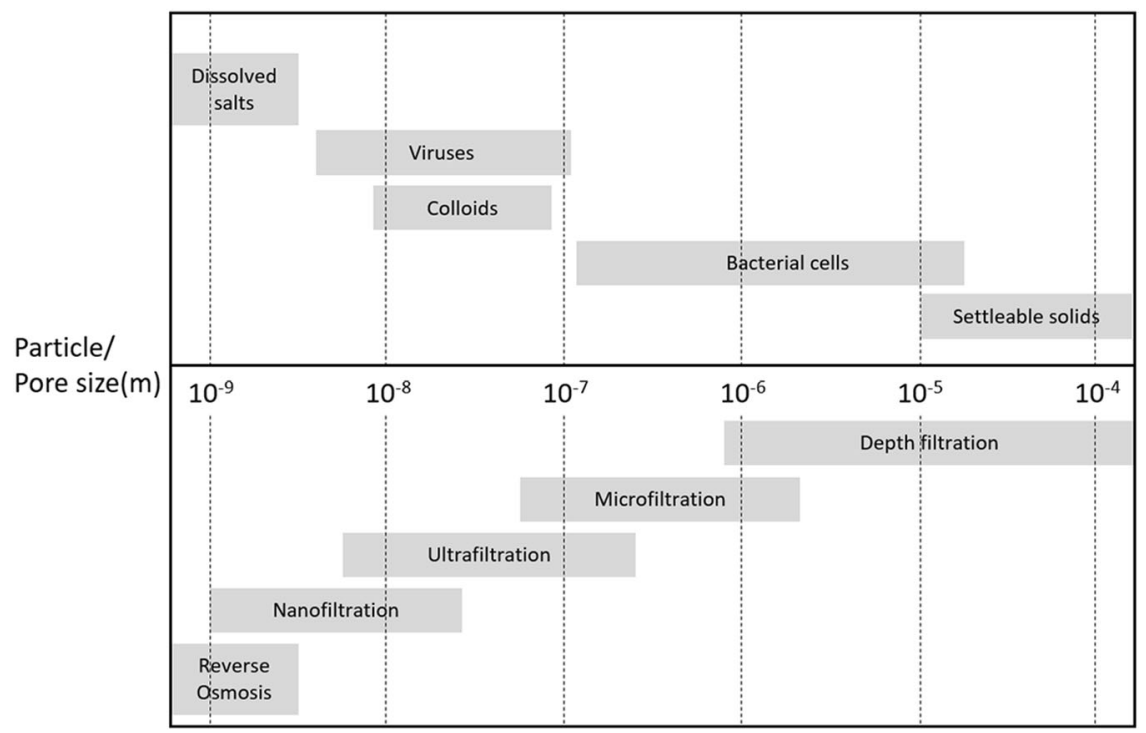

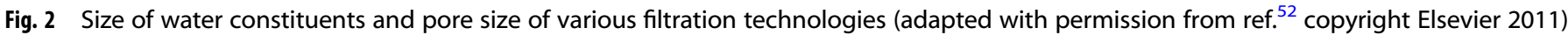

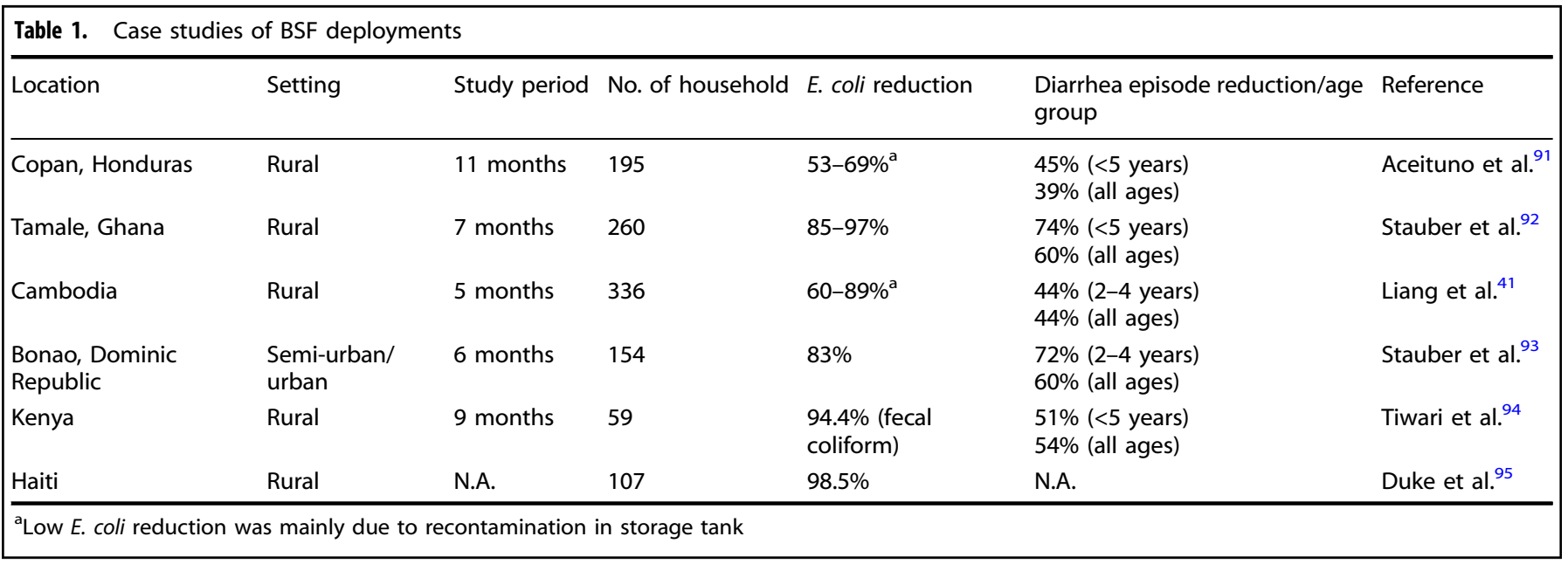

Biosand filtration. BSF is a promising POU treatment process with more than 500,000 people using it worldwide. It can be easily constructed using raw materials that are locally sourced. The concept of BSF is similar to that of a conventional slow sand filter. However, BSF experiences varying flowrate and intermittent filtration through the sand layer. The outlet of the POU is located higher than the sand layer, allowing the sand layer to be saturated with water throughout the operation. This allows for microbial growth, developing biofilm around the filter media and sand particles. Excessive biofilm growth in the biolayer forms the Schmutzdecke, which removes larger microorganisms, colloids, and contaminants from the water sources. ${ }^{35,36}$

$\mathrm{BSF}$ is capable of reducing turbidity and removing $E$. coli. While a new BSF POU filter only achieved $63 \%$ E. coli removal, $98 \%$ removal was observed in a mature filter. ${ }^{35}$ However, the treated water does not meet the WHO drinking water guideline. By replacing the sand with iron-coated sand, more than 2 log removals of $E$. coli was observed when it was fed with water with $>10^{3} \mathrm{CFU} / \mathrm{mL}$ E. coli concentration. ${ }^{37}$ Increasing the flowrate, however, reduced the retention time and overall effectiveness of the filter. ${ }^{38}$ This indicated that the sizing of the BSF is crucial in order to accommodate the target loading water volume. Removal of coliform will not be effective if the system is under-designed. Virus removal was also observed in BSF, achieving $1.3 \mathrm{log}$ removals of echovirus 12 with fresh BSF and 2.2 log removal after maturation. ${ }^{38}$ Filter depth was found to affect the removal of virus. A BSF with $54.3 \mathrm{~cm}$ filter depth achieved $6.7 \mathrm{log}$ reduction of MS2, while a BSF with $5.4 \mathrm{~cm}$ filter depth achieved $3.4 \mathrm{log}$ reduction of MS2. ${ }^{36}$ In a separate study, BSF with $10 \%$ zero-valent iron achieved more than $5 \log$ MS2 and rotavirus removal. ${ }^{39}$ This indicated that virus removal was mainly due to sorption to the filter media. Anaerobic BSF, with addition of ferrous iron, was also found to be able to reduce arsenic contamination in water. ${ }^{40}$ These studies showed that the filter media would affect the type of contaminant removed by BSF and the potential to remove other contaminants.

BSF has shown success in reducing diarrhea episode globally. It has also been shown to have a long filter life, with a BSF in Cambodia lasting up to 8 years of continuous usage. ${ }^{41}$ BSFs have been deployed in real-world condition to treat water sources. The performance of BSFs deployment in various countries is summarized in Table 1.

Membrane filtration. Membrane filtration is a mature technology and is one of the most effective drinking water treatment processes. Clasen et al. ${ }^{42}$ concluded that membrane filtration is the most effective means of preventing diarrhea. It provides an absolute barrier for microorganisms, retaining them within the water source. However, membrane filters require an external 
Table 2. Membrane filtration POU deployment in Asia

\begin{tabular}{|c|c|c|c|c|c|c|}
\hline (Switzerland) & Lifestraw community & Hollow fiber $(0.02 \mu \mathrm{m})$ & Gravity & N.A. & USD329.95 & $\begin{array}{l}\text { Cryptosporidium oocysts } \\
(>3.9 \mathrm{log})^{96}\end{array}$ \\
\hline Hydrologic (Cambodia) & $\begin{array}{l}\text { Super Tunsai water } \\
\text { filter }\end{array}$ & Ceramic $(0.2 \mu \mathrm{m})$ & Gravity & $2-3 \mathrm{~L} / \mathrm{h}$ & USD38 & Bacteria $(>4 \log )^{47}$ \\
\hline Wateroam (Singapore) & ROAMplus & $\begin{array}{l}\text { Polyethersulfone }(0.02 \\
\mu \mathrm{m})\end{array}$ & $\begin{array}{l}\text { Integrated } \\
\text { pump }\end{array}$ & $250 \mathrm{~L} / \mathrm{h}$ & USD260 & Coliform $(>7 \text { log })^{44}$ \\
\hline Icon Lifesaver (UK) & Lifesaver Jerrycan & Ultrafiltration & $\begin{array}{l}\text { Integrated } \\
\text { pump }\end{array}$ & $75 \mathrm{~L} / \mathrm{h}$ & $£ 203.99$ & $\begin{array}{l}\text { R. terrigena }(>6 \log )^{45} \\
\text { MS2 virus }(>3 \log )\end{array}$ \\
\hline $\begin{array}{l}\text { Skyjuice foundation } \\
\text { (Australia) }\end{array}$ & Skyhydrant & PVDF $(0.04 \mu \mathrm{m})$ & Gravity & $1000 \mathrm{~L} / \mathrm{h}$ & N.A. & $\begin{array}{l}\text { Coliform }(>6 \text { log) } \\
\text { Cryptosporidium }(>6 \text { log) } \\
\text { Virus }(>3 \text { log })^{46}\end{array}$ \\
\hline
\end{tabular}

driving force such as electrical pumping. In the past decade, innovative designs and optimization allowed manufacturers to produce off-grid or non-electric driven membrane filter systems. Companies such as Wateroam, Icon lifesaver, and Villagepump integrated a manual pump within the membrane system, making the system grid-independent. Grid-independent water filtration system is crucial because many places around the world do not have continuous electricity supply. In South Asia, more than $50 \%$ of people living in rural areas do not have electricity. ${ }^{43}$ Therefore, grid-independent water filtration system is highly recommended in rural areas. A list of membrane filtration POU designed for developing communities deployed in Asia is tabulated in Table 2.

Though some membrane filtration systems have high initial cost, their flowrate and lifespan resulted in lower cost per litre of water produced. ROAMplus, a product from WateROAM, has an estimated lifespan of 2 years and a flowrate of $250 \mathrm{~L} / \mathrm{h}$. This resulted in an estimated cost of <USD 0.001 per litre, assuming the system is used $5 \mathrm{~h}$ per day, 350 days per year. In addition, comparing with BSF, membrane filter systems have significant higher flow rate. The high membrane packing density allows for high membrane surface area to volume ratio, resulting in higher flow rate. In addition, membrane filtration is capable of removing turbidity and pathogens. As seen from Table 2, ultrafiltration (UF) membrane systems achieve more than 6 log bacteria removal, ${ }^{44-}$ ${ }^{46}$ while microfiltration (MF) membrane systems achieve at least 4 log bacteria removal. ${ }^{47}$ Table 2 also shows that UF is capable of achieving more than 3 log virus removal. This high microorganism removal makes membrane systems more reliable and effective than conventional ceramic candle filters. ${ }^{48}$ Long-term studies revealed that membrane filtration systems, with proper maintenance, could consistently produce similar water quality results ${ }^{48,49}$ over extended periods of time.

Challenges and potential solutions. Though the idea of household slow sand filtration existed since the 1980s, extensive researches were only conducted since 2000. BSF demonstrated great potential for water treatment. Changes in operating conditions and filter media compositions may yield different results. One solution is to add biochar into BSF systems to improve pathogen removal. Similar to BSF, biochar is a low-cost and sustainable adsorbent that can be made from locally sourced materials. Through pyrolysis or degasification, organic materials can be converted into biochar. ${ }^{50}$ While it is primarily used for adsorption, it was found to be able to inactivate microorganisms. ${ }^{51}$ The addition of biochar into BSF may improve pathogen, organic contaminant, and heavy metal removals. However, the capability of pathogen removal is dependent on the biochar characteristics and operating condition. While BSF is able to reduce pathogens in the water, the absence of residual disinfectants could allow recontamination to occur. In addition, disinfection process is required downstream to ensure the treated water is capable of meeting the WHO drinking water guidelines.

While both BSF and membrane POU systems are able to remove pathogens effectively, they are unable to remove dissolved solids. The pore sizes of the MF or UF membranes are too large to retain dissolved solids, allowing the dissolved solids to permeate through. ${ }^{52}$ Dissolved solids such as heavy metals can be removed by dense membrane systems such as the reverse osmosis (RO) process, which is a commonly used dense membrane to remove dissolved solids from water sources in desalination. ${ }^{53}$ However, due to the complexity of RO system, requirement for stable electricity supply, and maintenance, RO systems are not commonly deployed in rural areas. In addition, the use of RO also increases the operation cost of the water treatment system. Another dense membrane process, forward osmosis, is a favorable technology in treating chemically contaminated wastewater. Products from Hydration Technology Innovations had developed POU systems that utilized forward osmosis to filter water source. The draw solution, however, is not reusable and the system has a relatively low water flux.

Unfavorable water condition may result in rapid fouling of membrane, increasing maintenance frequency, and reducing water production. Water with elevated concentration of dissolved organic matters (DOM) will result in organic fouling. The formation of biofilm on membrane surface results in biofouling. Lastly, accumulation of particles on membrane surface as well as within the membrane pores results in particle fouling. These fouling will reduce permeate flux and water filtration rate. Chemical cleaning and backwash will be required once the flux is below acceptable limits. $^{54}$ In cases where water conditions are unfavorable, pretreatment is required prior to membrane process.

\section{DISINFECTION}

Unlike the abovementioned two technologies, where microorganisms are removed from the water, disinfection resulted in the inactivation or death of microorganisms. ${ }^{14}$ Due to different microorganisms that potentially exist in water source, the type of disinfectant and dosage/exposure time differ from one microorganism to another. In addition, different disinfectants have different microorganism inactivation/destruction mechanisms. 
Solar disinfection (SoDis)

Solar disinfection (SoDis) is a low-cost effective disinfection POU that involves the prolong exposure of water in polyethylene terephthalate (PET) or glass bottle under sunlight, ${ }^{55}$ allowing UV to transmit into the water. Prolong exposure also increases the temperature of the water in the bottle. Pathogens are inactivated by both the UV from the sun and the increase in water temperature.

There were many research on SoDis in the past 2 decades. Berney et al. ${ }^{56}$ revealed that inactivation of Vibrio cholerae starts once water temperature is risen beyond $40^{\circ} \mathrm{C}$. E. coli were found to have slightly higher heat resistant. Reduction in E. coli occurred when water temperature was risen beyond $45^{\circ} \mathrm{C}^{56,57}$ Temperature itself, however, is insufficient in disinfecting water source. In a separate study, a transparent bottle performed slightly better than a fully black bottle (negating effect of UV), even though the temperature within the transparent bottle was lower. After $4 \mathrm{~h}$ of solar exposure, coliforms were not detected in the transparent bottle but were detected in the fully black bottle. ${ }^{58}$ SoDis is also effective in turbid water. Though turbidity reduced the effectiveness of transmittance of UV, the scattering of UV light within the bottle improved the efficiency. ${ }^{55}$ A study revealed that SoDis was able to disinfect and achieve 6-log E. coli removal with well water of turbidity up to 100 NTU. ${ }^{59}$

Research had been done to improve the performance of SoDis. The design of the reflector and bottle can affect the SoDis treatment. Kalt et al. ${ }^{60}$ had demonstrated that a double parabolic collector was able to increase the water temperature to above $45^{\circ}$ $C$ within $42 \mathrm{~min}$, with $E$. coli concentration below detection limit after $20 \mathrm{~min}$. In another study, transparent bottles on a double parabola concentrator and large concentrator were able to maintain temperature over $45^{\circ} \mathrm{C}$ for $3 \mathrm{~h}$ and $6 \mathrm{~h}$, respectively. Total coliform concentration of both concentrator systems was below the detection limit within $4 \mathrm{~h}^{58}$ In the same study, the use of a half-black bottle on the large concentrator was able to maintain temperature over $45^{\circ} \mathrm{C}$ throughout the day, with peak temperature reaching $75^{\circ} \mathrm{C}$. Bottles and bags made from other materials can also be used for SoDis. Polyethylene (PE) bag and polypropylene copolymer (PPCO) outperformed PET bottles due to its higher UVB transmittance, with more than 2 log bacteria removal at $450 \mathrm{~kJ} / \mathrm{m}^{2}$ of UV dose. ${ }^{61,62}$ However, gas chromatography-mass spectrometry of water samples revealed degradation of low density PE bag after prolong solar exposure, producing 2,4-di-tert-butylphenol. ${ }^{63}$ Addition of addictive (100 mg/L sodium percarbonate, $100 \mathrm{mg} / \mathrm{L}$ ascorbic acid, and 20 $\mu \mathrm{g} / \mathrm{L}$ copper sulfate) improved inactivation rate of $E$. coli, reducing the 3 log inactivation time from 2.93 to $1.95 \mathrm{~h}^{62}$

SoDis has proven to be a simple, low-cost, and effective disinfecting technique. It has been deployed in different places around the world, serving more than 30 countries worldwide. ${ }^{64}$ Field studies of SoDis are summarized in Table 3. However, SoDis does have its disadvantages; it is heavily dependent on weather condition; and it requires an exposure period of more than $48 \mathrm{~h}$ on cloudy days. ${ }^{65}$ Commercial product like WADI ${ }^{66}$ can assist users with a more accurate determination of whether the water had been disinfected. In addition, SoDis is unable to remove chemical pollutants in the water.

\section{Nanotechnology}

Extensive research in nanotechnologies in the past 2 decades have opened new door for development of water treatment techniques. Nanoparticles, with sizes between 1 and $100 \mathrm{~nm}$, exhibit different characteristics and have a higher specific surface area than their conventional macro-scale counterparts. ${ }^{67}$ This makes nanoparticles more efficient in water treatment. Nanoparticles have been applied in various fields such as adsorption, membrane development, and advanced oxidation processes. For instance, development of Fe-impregnated carbon nanofiber has shown potential in arsenic removal via adsorption, ${ }^{68}$ while nanomaterials added new functionalities and benefits into membrane. ${ }^{69}$ Nanotechnology had been applied in POU as well, namely, $\mathrm{TiO}_{2}$ and $\mathrm{Ag}$ nanoparticles.

Titanium dioxide nanoparticles. Titanium dioxide is a widely used photocatalysis; it is applied in many products and is the most produced nanoparticle. ${ }^{70}$ Upon exposure to UV-vis light, $\mathrm{TiO}_{2}$ generates $\mathrm{OH}$ radicals, $\mathrm{H}_{2} \mathrm{O}_{2}, \mathrm{O}_{2}{ }^{-}$, and $\mathrm{O}_{2}$, which can oxidize organics and inactivate microorganisms. ${ }^{71,72}$ During the process, $\mathrm{TiO}_{2}$ is regenerated, making it available for further reactive oxygen species generation. This photocatalytic property allows $\mathrm{TiO}_{2}$ to be applied in different water treatment processes. $\mathrm{TiO}_{2}$ nanoparticles have been applied onto the membrane, reducing biofouling and increasing hydrophilicity. ${ }^{69}$ In the past decade, titanium dioxide has made its way into commercial POU water treatment. Solarbag, a product by Puralytics, lined $\mathrm{TiO}_{2}$ nanoparticles within the bag to remove contaminants and disinfect the water. ${ }^{73}$

Research has shown that $\mathrm{TiO}_{2}$ can enhance SoDis effect. $\mathrm{TiO}_{2}$ immobilized within the water treatment system was able to reduce $E$. coli concentration to below detection limit within $4 \mathrm{~h}$, while an uncoated system took more than $5 \mathrm{~h} .^{71}$ It has also been reported that suspended $\mathrm{TiO}_{2}$ yield better results than immobilized form due to the increased surface area. However, retaining the suspended $\mathrm{TiO}_{2}$ and separating them from the treated water proved to be a challenge. ${ }^{74} \mathrm{~A}$ review by Laxma Reddy et al. ${ }^{74}$ summarized the photocatalytic disinfection property of $\mathrm{TiO}_{2}$ on bacteria, fungi, virus, protozoa, and algae.

Silver nanoparticles. Silver nanoparticles (AgNP) is another nanotechnology that is widely used in consumer product. Though its production is $2 \%$ of $\mathrm{TiO}_{2}$ nanoparticles, it has been applied in over 400 commercial products $^{70}$ due to its antimicrobial properties. It is a well-established fact that silver is toxic to microorganisms. However, the bactericidal effect of AgNP differs from silver ions. Silver nanoparticles attached to the bacterial cell membrane electrostatically, ${ }^{75}$ disrupting its permeability and damaging it. It

\begin{tabular}{|c|c|c|c|c|c|}
\hline Kenya & Rural & 12 weeks & 206 children & $9 \%$ (5-16 years old) & Conroy et al. ${ }^{57}$ \\
\hline Bolivia & Rural & 1 year & 376 children & $33 \%$ ( $\leq 5$ years) & Mausezahl et al. ${ }^{64}$ \\
\hline Cambodia & Rural & 1 year & 928 children & $\begin{array}{l}50 \%(\leq 5 \text { years })^{a} \\
63 \%(\leq 5 \text { years })^{b}\end{array}$ & McGuigan et al. ${ }^{98}$ \\
\hline
\end{tabular}


can also enter and bioaccumulate within the bacterial cell and interact with its DNA, damaging the cell. ${ }^{76,77}$ Inhibition of bacteria growth was observed at $5 \mathrm{mg} / \mathrm{L}$ of $\mathrm{AgNP}{ }^{78}$ with $100 \%$ inhibition at $50 \mathrm{mg} / \mathrm{L}$ of AgNP. ${ }^{75}$ Ceramic filter coated with AgNP was also effective in bacteria removal, with $92.82 \%$ E. coli removal and $87.11 \%$ coliform removal. ${ }^{79}$ By coating AgNP onto polyurethane filters, more than 5 log bacteria removal was observed. ${ }^{80}$ AgNP is also toxic to virus such as norovirus ${ }^{81}$ and poliovirus. ${ }^{82}$ However, AgNP was found to be ineffective against MS2 bacteriophage. ${ }^{83}$

Silver nanoparticles has made its way into POU water treatment systems for the developing communities. Tata Swach, a water filter that uses rice husk ash with AgNP, is able to achieve $1 \log E$. coli removal. ${ }^{84}$ Folia filter by Folia water is another filter coated with copper and silver nanoparticle for disinfection purpose. A research by the co-founder, Dankovich, ${ }^{85}$ showed that more than $6 \log$ E. coli removal was achieved with $1.6 \mathrm{mg} \mathrm{AgNP/g}$ filter paper. Field study revealed more than $4 \log E$. coli removal by copper and silver nanoparticles coated filter paper. ${ }^{86}$

Drawbacks. Both $\mathrm{TiO}_{2}$ and silver nanoparticles had showed great potential in advanced oxidation process and disinfection. However, the long-term effect of nanoparticles is largely unknown. ${ }^{87}$ Improper disposal and leaching can result in nanoparticles entering the environment. Nanoparticles can also enter aquatic animal by ingestion, gills, or body walls. ${ }^{88} \mathrm{TiO}_{2}$ and AgNP, at elevated concentration, are toxic to marine life ${ }^{89}$ high concentration of AgNP can affect mammalian cells such as reducing cell vitality and mitochondrial function, and can cause cell membrane leakages. ${ }^{90}$ Therefore, proper disposal method should be incorporated into the systems, reducing the release of nanoparticles into the environment. In addition, although there are no guidelines on nanoparticles concentration in drinking water, leaching of nanoparticles into treated drinking water should be systematically investigated. Lastly, in region where nanoparticle technologies had been implemented, nanoparticle concentration can be monitored to observe the possible environmental fate and effects on the environment.

\section{CONCLUDING REMARKS AND PERSPECTIVE}

Technologies implemented in POU systems are effective in removing pathogens and have successfully reduced diarrhea episodes. The systems are simple to use with minimal maintenance. Optimization and development allowed flocculants to be packaged into POU sachets. Research in BSF has optimized the BSF depth and filtration flow rate. Development in membrane technologies has allowed water filtration process to be gridindependent. In addition, nanotechnologies have opened new opportunities for development in POU systems.

However, to successfully ensure removal of pathogens, multibarrier approach should be adopted. Users can couple filtration with disinfection, such as BSF together with SoDis, to minimize the risk of bacterial infection. In addition, the use of external storage might result in recontamination, as shown in the case studies in BSF deployment. Users should have a clean bucket that is primarily used for drinking water storage.

Several challenges still need to be addressed for the abovementioned technologies. Firstly, inorganic coagulants and flocculants have shown to be recoverable and reusable in drinking water treatment, reducing the OPEX. The recovery process, however, uses high concentration of alkaline and acid, resulting in high cost. Therefore, the stability of the recovered coagulant and the number of times it can be reused should be further investigated and optimized. Secondly, anaerobic BSF with ferrous iron has shown to be able to remove arsenic. This shed new light in the heavy metal removal by BSF technology. Arsenic poisoning is a serious problem encountered across the world. An improved arsenic removal could be achieved by varying the ferrous iron content, acetic acid addition, or the operating parameter of the BSF system. However, the mechanism of arsenic removal by the BSF system is still unknown. Nonetheless, this discovery could potentially widen its application in the treatment of arsenic-rich groundwater. In addition, biochar can be incorporated into BSF to improve pathogen and contaminant removal. Even though biochar needs to be replaced periodically, it can be made using locally sourced materials. The long-term effect of nanoparticles on the environment and human health in the rural setting has not been extensively monitored and evaluated. Improper disposal might release the nanoparticles into the environment. Suppliers and distributors should educate the users on proper disposal of nanoparticle products. In addition, the environmental fate of nanoparticles in the developing communities should be studied.

Lastly, while filtration and disinfection technologies are capable of removing pathogens from water sources, they are unable to effectively remove dissolved contaminants such as arsenic and chromium. These dissolved contaminants will cause chronic health issues if this water is consumed. Prior to consumption, pretreatment or post-treatment such as adsorption, coagulation, and ion exchange are required to reduce and remove these harmful contaminants if they are present.

\section{AUTHOR CONTRIBUTIONS}

C.K.P. conducted the detailed search and review of published relevant literatures and wrote the draft manuscript. H.Y.N. initiated this topic as a review paper, provided guidance on the content and structure of the manuscript, and amended the manuscript.

\section{ADDITIONAL INFORMATION}

Competing interests: The authors declare no competing interests.

Publisher's note Springer Nature remains neutral with regard to jurisdictional claims in published maps and institutional affiliations.

\section{REFERENCES}

1. UNICEF. Progress on Sanitation and Drinking Water: 2015 Update and MDG Assessment (World Health Organization, 2015). https://doi.org/10.1007/s13398014-0173-7.2.

2. UNICEF. A Mid-Term Assessment of Progress. Meeting the Development. (2004).

3. Griffiths, J. K. Waterborne diseases. in International Encyclopedia of Public Health, Vol. 7 (Elsevier, 2008).

4. Plutzer, J. \& Karanis, P. Neglected waterborne parasitic protozoa and their detection in water. Water Res. 101, 318-332 (2016).

5. Pegram, G. C., Rollins, N. \& Espey, Q. Estimating the costs of diarrhoea and epidemic dysentery in KwaZulu-Natal and South Africa. Water SA 24, 11-20 (1998).

6. WHO. Diarrhoeal Disease. Fact Sheets 1-4 (2017). Available at: http://www.who.int/ mediacentre/factsheets/fs330/en/.

7. Kotloff, K. L. et al. Burden and aetiology of diarrhoeal disease in infants and young children in developing countries (the Global Enteric Multicenter Study, GEMS): a prospective, case-control study. Lancet 382, 209-222 (2013).

8. Nienie, A. B. et al. Microbiological quality of water in a city with persistent and recurrent waterborne diseases under tropical sub-rural conditions: the case of Kikwit City, Democratic Republic of the Congo. Int. J. Hyg. Environ. Health 220, 820-828 (2017)

9. Efstratiou, A., Ongerth, J. E. \& Karanis, P. Waterborne transmission of protozoan parasites: review of worldwide outbreaks - an update 2011-2016. Water Res. 114, 14-22 (2017).

10. WHO. Guidelines for Drinking-water Quality, Vol. 1 (World Health Organization, 2006).

11. Betancourt, W. Q. \& Rose, J. B. Drinking water treatment processes for removal of Cryptosporidium and Giardia. Vet. Parasitol. 126, 219-234 (2004).

12. Mankad, A. \& Tapsuwan, S. Review of socio-economic drivers of community acceptance and adoption of decentralised water systems. J. Environ. Manag. 92, 380-391 (2011).

13. Ramavandi, B. Treatment of water turbidity and bacteria by using a coagulant extracted from Plantago ovata. Water Resour. Ind. 6, 36-50 (2014). 
14. Ratnayaka, D. D., Brandt, M. J. \& Johnson, K. M. Disinfection of water. Water Supply. (2009). https://doi.org/10.1016/B978-0-7506-6843-9.00019-6.

15. Metcalf \& Eddy. Wastewater Engineering Treatment and Reuse (McGraw-Hill, 2003)

16. Jiang, J. Q. The role of coagulation in water treatment. Curr. Opin. Chem. Eng. 8, 36-44 (2015).

17. Crump, J. A. et al. Effect of point-of-use disinfection, flocculation and combined flocculation-disinfection on drinking quality in western Kenya. J. Appl. Microbiol. 97, 225-231 (2004)

18. Nicholas, R. D., Kim, R. F., James, H. O. \& Richard, J. M. Controlling Cryptosporidium oocysts using conventional treatment. Am. Water Works Assoc. 93, 64-76 (2001)

19. Abebe, L. S., Chen, X. \& Sobsey, M. D. Chitosan coagulation to improve microbial and turbidity removal by ceramicwater filtration for household drinking water treatment. Int. J. Environ. Res. Public Health 13, (2016).

20. Sobsey, M. D. Managing water in the home: accelerated health gains from improved water supply. World Health 8, 1-83 (2004).

21. Souter, P. F. et al. Evaluation of a new water treatment for point-of-use household applications to remove microorganisms and arsenic from drinking water. J. Water Health 1, 73-84 (2003).

22. Baddache, F. Procter \& Gamble: Providing Safe Drinking Water to the Poor The Need for Drinkable Water in Developing Countries. (2007).

23. Reller, M. E. et al. A randomized controlled trial of household-based flocculantdisinfectant drinking water treatment for diarrhoea prevention in rural Guatemala. Am. J. Trop. Med. Hyg. 69, 441-449 (2003).

24. Sung, M. H. et al. Natural and edible biopolymer poly-gama-glutamic acid: synthesis, production, and applications. Chem. Rec. 5, 352-366 (2005)

25. Salehizadeh, H. \& Yan, N. Recent advances in extracellular biopolymer flocculants. Biotechnol. Adv. 32, 1506-1522 (2014).

26. Campos, V., Fernandes, A. R. A. C., Medeiros, T. A. M. \& Andrade, E. L. Physicochemical characterization and evaluation of PGA bioflocculant in coagulation-flocculation and sedimentation processes. J. Environ. Chem. Eng. 4 3753-3760 (2016).

27. Carvajal-Zarrabal, $\mathrm{O}$. et al. Treatment of vinasse from tequila production using polyglutamic acid. J. Environ. Manag. 95, S66-S70 (2012)

28. Gargouri, B., Karray, F., Mhiri, N., Aloui, F. Sayadi, S. Application of a continuously stirred tank bioreactor (CSTR) for bioremediation of hydrocarbon-rich industrial wastewater effluents. J. Hazard. Mater. 189, 427-434 (2011).

29. Taniguchi, M. et al. Proposals for wastewater treatment by applying flocculating activity of cross-linked poly- $\gamma$-glutamic acid. J. Biosci. Bioeng. 99, 245-251 (2005)

30. PolyGlu International. What is PolyGlu? Coagulants Polyglutamate. Available at: http://www.polyglu.net/polyglu_e/aboutus/index.html. (Accessed 2 Jul 2017).

31. Mark, S. S., Crusberg, T. C., DaCunha, C. M. \& Di lorio, A. A. A heavy metal biotrap for wastewater remediation using poly- $\gamma$-glutamic acid. Biotechnol. Prog. 22, 523-531 (2006)

32. Mutou, M. \& Hirota, F. US 2011/0046040 A1. 10 (2011).

33. Keeley, J., Jarvis, P., Smith, A. D. \& Judd, S. J. Coagulant recovery and reuse for drinking water treatment. Water Res. 88, 502-509 (2016).

34. Jeon, S. B. et al. Self-powered electro-coagulation system driven by a wind energy harvesting triboelectric nanogenerator for decentralized water treatment. Nano Energy 28, 288-295 (2016).

35. Stauber, C. E. et al. Characterisation of the biosand filter for E. coli reductions from household drinking water under controlled laboratory and field use conditions. Water Sci. Technol. 54, 1-7 (2006)

36. Wang, $\mathrm{H}$. et al. MS2 bacteriophage reduction and microbial communities in biosand filters. Environ. Sci. Technol. 48, 6702-6709 (2014).

37. Ahammed, M. M. \& Davra, K. Performance evaluation of biosand filter modified with iron oxide-coated sand for household treatment of drinking water. Desalination 276, 287-293 (2011).

38. Elliott, M. A., Stauber, C. E., Koksal, F., DiGiano, F. A. \& Sobsey, M. D. Reductions of E. coli, echovirus type 12 and bacteriophages in an intermittently operated household-scale slow sand filter. Water Res. 42, 2662-2670 (2008).

39. Bradley, I., Straub, A., Maraccini, P., Markazi, S. \& Nguyen, T. H. Iron oxide amended biosand filters for virus removal. Water Res. 45, 4501-4510 (2011).

40. Snyder, K. V., Webster, T. M., Upadhyaya, G., Hayes, K. F. \& Raskin, L. Vinegaramended anaerobic biosand filter for the removal of arsenic and nitrate from groundwater. J. Environ. Manag. 171, 21-28 (2016).

41. Liang, K., Sobsey, M. \& Stauber, C. Improving Household Drinking Water QualityUse of BioSand Filters in Cambodia. Water and Sanitation Program. (2010).

42. Clasen, T. F., Roberts, I. G., Rabie, T., Schmidt, W. P. \& Cairncross, S. Interventions to improve water quality for preventing diarrhoea. Cochrane Database Syst. Rev. 3 , (2006).

43. Palit, D. \& Chaurey, A. Off-grid rural electrification experiences from South Asia. Green Energy Technol. 116, 75-104 (2013)

44. Setsco Services. Test Report. (2017).
45. Biological Consulting Services. Biological Filtration Efficacy Test Study of the Provided Icon Lifesaver ${ }^{\circledast}$ Jerrycan Filter Units. (2016).

46. SkyJuice Foundation. Skyhydrant Ultrafiltration Unit-User Guide Data Sheet. 1-24. Available at: http://www.skyjuice.org.au/wp-content/uploads/2016/10/ SJ_SkyHydrant_UserGuide_DataSheet.pdf. (Accessed 3 Jul 2017).

47. The Gold Standard. Production and Dissemination of Ceramic Water Purifiers (CWPs) by Hydrologic, in the Kingdom of Cambodia. (2012).

48. Pérez-Vidal, A., Diaz-Gómez, J., Castellanos-Rozo, J. \& Usaquen-Perilla, O. L. Long term evaluation of the performance of four point-of-use water filters. Water Res. 98, 176-182 (2016).

49. Frechen, F. B., Exler, H., Romaker, J. \& Schier, W. Long-term behaviour of a gravitydriven dead end membrane filtration unit for potable water supply in cases of disasters. Water Sci. Technol. Water Supply 11, 39-44 (2011).

50. Gwenzi, W., Chaukura, N., Mukome, F. N. D., Machado, S. \& Nyamasoka, B. Biochar production and applications in sub-Saharan Africa: opportunities, constraints, risks and uncertainties. J. Environ. Manag. 150, 250-261 (2015).

51. Gwenzi, W., Chaukura, N., Noubactep, C. \& Mukome, F. N. D. Biochar-based water treatment systems as a potential low-cost and sustainable technology for clean water provision. J. Environ. Manag. 197, 732-749 (2017).

52. Judd, S. \& Judd, C. The MBR Book (Butterworth-Heinemann, 2011). https://doi.org/ 10.1016/B978-0-08-096682-3.10002-2.

53. Wimalawansa, S. J. Purification of contaminated water with reverse osmosis: effective solution of providing clean water for human needs in developing countries. Int. J. Emerg. Technol. Adv. Eng. 3, 75-89 (2013).

54. Gao, W. et al. Membrane fouling control in ultrafiltration technology for drinking water production: a review. Desalination 272, 1-8 (2011).

55. Wegelin, M., Canonica, S., Mechsner, K., Pesaro, F. \& Metzler, A. Solar water disinfection: scope of the process and analysis of radiation experiments. J. Water Supply: Res. Technol. - AQUA 43, 154-169 (1994).

56. Berney, M., Weilenmann, H. U., Simonetti, A. \& Egli, T. Efficacy of solar disinfection of Escherichia coli, Shigella flexneri, Salmonella typhimurium and Vibrio cholerae. J. Appl. Microbiol. 101, 828-836 (2006).

57. McGuigan, K. G., Joyce, T. M., Conroy, R. M., Gillespie, J. B. \& Elmore-Meegan, M. Solar disinfection of drinking water contained in transparent plastic bottles: characterizing the bacterial inactivation process. J. Appl. Microbiol. 84, 1138-1148 (1998).

58. Martín-Domínguez, A., Alarcón-Herrera, M. T., Martín-Domínguez, I. R. \& GonzálezHerrera, A. Efficiency in the disinfection of water for human consumption in rural communities using solar radiation. Sol. Energy 78, 31-40 (2005).

59. Keogh, M. B. et al. Capability of 19-L polycarbonate plastic water cooler containers for efficient solar water disinfection (SODIS): field case studies in India, Bahrain and Spain. Sol. Energy 116, 1-11 (2015).

60. Kalt, P. et al. A solar disinfection water treatment system for remote communities Procedia Eng. 78, 250-258 (2014)

61. Lawrie, K. et al. UV dosimetry for solar water disinfection (SODIS) carried out in different plastic bottles and bags. Sens. Actuators B, Chem. 208, 608-615 (2015).

62. Fisher, M. B., Iriarte, M. \& Nelson, K. L. Solar water disinfection (SODIS) of Escherichia coli, Enterococcus spp., and MS2 coliphage: effects of additives and alternative container materials. Water Res. 46, 1745-1754 (2012).

63. Danwittayakul, S., Songngam, S., Fhulua, T., Muangkasem, P. Sukkasi, S. Safety and durability of low-density polyethylene bags in solar water disinfection applications. Environ. Technol. 3330, 1-10 (2016).

64. Mäusezahl, D. et al. Solar drinking water disinfection (SODIS) to reduce childhood diarrhoea in rural Bolivia: a cluster-randomized, controlled trial. PLoS Med. 6, (2009).

65. Fisher, M. B., Keenan, C. R., Nelson, K. L. \& Voelker, B. M. Speeding up solar disinfection (SODIS): effects of hydrogen peroxide, temperature, $\mathrm{pH}$, and copper plus ascorbate on the photoinactivation of E. coli. J. Water Health 6, 35-51 (2008).

66. Helioz. WADI-The Indicator for SoDis. 17-20 (2017). Available at: https://www. helioz.org/overview.php. (Accessed 7 Jul 2017).

67. Tesh, S. J. \& Scott, T. B. Nano-composites for water remediation: a review. Adv. Mater. 26, 6056-6068 (2014).

68. Gupta, A. K., Deva, D., Sharma, A., \& Verma, N. Fe-grown carbon nanofibers for removal of arsenic (V) in wastewater. Industrial and Engineering Chemistry Research 49, 7074-7084 (2010).

69. Yin, J. \& Deng, B. Polymer-matrix nanocomposite membranes for water treatment. J. Memb. Sci. 479, 256-275 (2015).

70. Vance, M. E. et al. Nanotechnology in the real world: redeveloping the nanomaterial consumer products inventory. Beilstein J. Nanotechnol. 6, 1769-1780 (2015).

71. Alrousan, D. M. A., Polo-López, M. I., Dunlop, P. S. M., Fernández-lbáñez, P. \& Byrne, J. A. Solar photocatalytic disinfection of water with immobilised titanium dioxide in re-circulating flow CPC reactors. Appl. Catal. B 128, 126-134 (2012).

72. Fujishima, A., Rao, T. N. \& Tryk, D. A. Titanium dioxide photocatalysis. J. Photochem. Photobiol. C: Photochem. Rev. 1, 1-21 (2000). 
73. Owen, M., Thorne, J. \& Sammi, M. K. Ultraviolet photoreactor for the purification of fluids. (2013).

74. Laxma Reddy, P. V., Kavitha, B., Kumar Reddy, P. A. \& Kim, K. H. TiO 2 -based photocatalytic disinfection of microbes in aqueous media: a review. Environ. Res. 154, 296-303 (2017).

75. Sondi, I. \& Salopek-Sondi, B. Silver nanoparticles as antimicrobial agent: a case study on E. coli as a model for Gram-negative bacteria. J. Colloid Interface Sci. 275, 177-182 (2004).

76. Morones, J. R. et al. The bactericidal effect of silver nanoparticles. Nanotechnology 16, 2346-2353 (2005).

77. Choi, Y., Kim, H.-A., Kim, K.-W. \& Lee, B.-T. Comparative toxicity of silver nanoparticles and silver ions to Escherichia coli. J. Environ. Sci. 1-11 (2017). https://doi. org/10.1016/j.jes.2017.04.028.

78. Shrivastava, S. et al. Characterization of enhanced antibacterial effects of novel silver nanoparticles. Nanotechnology 18, 225103 (2007).

79. Kallman, E. N., Oyanedel-Craver, V. A. \& Smith, J. A. Ceramic filters impregnated with silver nanoparticles for point-of-use water treatment in rural Guatemala. J. Environ. Eng. 137, 407-415 (2010).

80. Jain, P. \& Pradeep, T. Potential of silver nanoparticle-coated polyurethane foam as an antibacterial water filter. Biotechnol. Bioeng. 90, 59-63 (2005).

81. Castro-Mayorga, J. L. et al. Antiviral properties of silver nanoparticles against norovirus surrogates and their efficacy in coated polyhydroxyalkanoates systems. LWT_Food Sci. Technol. 79, 503-510 (2017).

82. Huy, T. Q. et al. Cytotoxicity and antiviral activity of electrochemical-synthesized silver nanoparticles against poliovirus. J. Virol. Methods 241, 52-57 (2017).

83. You, J., Zhang, Y. \& Hu, Z. Bacteria and bacteriophage inactivation by silver and zinc oxide nanoparticles. Colloids Surf. B, Biointerfaces 85, 161-167 (2011).

84. He, D., Ikeda-Ohno, A., Boland, D. D. \& Waite, T. D. Synthesis and characterization of antibacterial silver nanoparticle-impregnated rice husks and rice husk ash. Environ. Sci. Technol. 47, 5276-5284 (2013).

85. Dankovich, T. A. Bactericidal Paper Containing Silver Nanoparticles for Water Treatment. 1992-1998 (2012).

86. Theresa, A. D., Jonathan, S. L., Natasha, P., Rebecca, D. \& James, A. S. Inactivation of bacteria from contaminated streams in Limpopo, South Africa by silver- or copper-nanoparticle paper filters. Environ. Sci. 16, 700-710 (2015).

87. Lin, $\mathrm{D}$. et al. Role of $\mathrm{pH}$ and ionic strength in the aggregation of $\mathrm{TiO}_{2}$ nanoparticles in the presence of extracellular polymeric substances from Bacillus subtilis. Environ. Pollut. 228, 35-42 (2017).

88. Nowack, B. \& Bucheli, T. D. Occurrence, behavior and effects of nanoparticles in the environment. Environ. Pollut. 150, 5-22 (2007).

89. Fabrega, J., Luoma, S. N., Tyler, C. R., Galloway, T. S. \& Lead, J. R. Silver nanoparticles: behaviour and effects in the aquatic environment. Environ. Int. 37, 517-531 (2011).
90. Tran, Q. H., Nguyen, V. Q. \& Le, A.-T. Silver nanoparticles: synthesis, properties, toxicology, applications and perspectives. Adv. Nat. Sci.: Nanosci. Nanotechnol. 4, 33001 (2013).

91. Fabiszewski De Aceituno, A. M., Stauber, C. E., Walters, A. R., Meza Sanche, R. E. \& Sobsey, M. D. A randomized controlled trial of the plastic-housing BioSand filter and its impact on diarrheal disease in Copan, Honduras. Am. J. Trop. Med. Hyg. 86, 913-921 (2012).

92. Stauber, C. E., Kominek, B., Liang, K. R., Osman, M. K. \& Sobsey, M. D. Evaluation of the impact of the plastic biosand filter on health and drinking water quality in rural tamale, Ghana. Int. J. Environ. Res. Public Health 9, 3806-3823 (2012).

93. Stauber, C. E., Ortiz, G. M., Loomis, D. P. \& Sobsey, M. D. A randomized controlled trial of the concrete biosand filter and its impact on diarrheal disease in Bonao, Dominican Republic. Am. J. Trop. Med. Hyg. 80, 286-293 (2009).

94. Tiwari, S. S. K., Schmidt, W. P., Darby, J., Kariuki, Z. G. \& Jenkins, M. W. Intermittent slow sand filtration for preventing diarrhoea among children in Kenyan households using unimproved water sources: randomized controlled trial. Trop. Med. Int. Health 14, 1374-1382 (2009).

95. Duke, W. F., Nordin, R. N., Baker, D. \& Mazumder, A. The use and performance of Biosand filters in the Artibonite Valley of Haiti: a field study of 107 households. Rural Remote Health 6, 570 (2006).

96. Vestergaard. LifeStraw Evidence Dossier. (2015).

97. Rose, A. Solar disinfection of water for diarrhoeal prevention in southern India. Arch. Dis. Child. 91, 139-141 (2005).

98. Mcguigan, K. G., Samaiyar, P., Du Preez, M., An, R. \& Conroy, M. High compliance randomized controlled field trial of solar disinfection of drinking water and its impact on childhood diarrhea in Rural Cambodia. Environ. Sci. Technol. 45, 7862-7867 (2011)

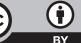

Open Access This article is licensed under a Creative Commons Attribution 4.0 International License, which permits use, sharing, adaptation, distribution and reproduction in any medium or format, as long as you give appropriate credit to the original author(s) and the source, provide a link to the Creative Commons license, and indicate if changes were made. The images or other third party material in this article are included in the article's Creative Commons license, unless indicated otherwise in a credit line to the material. If material is not included in the article's Creative Commons license and your intended use is not permitted by statutory regulation or exceeds the permitted use, you will need to obtain permission directly from the copyright holder. To view a copy of this license, visit http://creativecommons. org/licenses/by/4.0/.

(c) The Author(s) 2018 